\title{
THE APPROPRIATION OF THE GENRE OF NUPTIAL POETRY BY KATHARINA LESCAILJE (1649-1711)
}

\author{
Nina Geerdink
}

Love is a conqueror and a violator. When a bride is captured by Love, pity arises instead of jealousy or admiration. These are not themes one expects to encounter in a poem written to commemorate the cheerful occasion of marriage. Yet in some of the nuptial poems by the Dutch poet Katharina Lescailje (1649-1711) these are dominant themes. Marriage in her poems is often represented as a prison, which brings an end to one's freedom.

Recent research has regarded this as remarkable. On the basis of a semiotic reading of poems Lescailje wrote for female friends, Lia van Gemert concluded that we should consider the possibility that Lescailje harboured lesbian feelings for them. ${ }^{1}$ Van Gemert bases her argument partly on a nuptial poem. The negative tone Lescailje's poem takes to marriage could according to her reveal feelings of love for the bride and jealousy towards the bridegroom. ${ }^{2}$ Ellen Grabowsky has offered resistance to this interpretation on the basis of archival research revealing biographical evidence that problematises Van Gemert's interpretations. ${ }^{3}$ Grabowsky also points to similarities between this poem and some other nuptial poems by Lescailje. She contends that the negativity towards marriage in the poems for some women bears

\footnotetext{
${ }^{1}$ Gemert L. van, "Hiding Behind Words? Lesbianism in 17th-century Dutch Poetry", Thamyris: Mythmaking from Past to Present 2, 1 (1995) 11-44; and "De vrouwenzucht van Katharina Lescailje", in Gelderblom A.J. - Duits H. - Smits-Veldt M.B. (eds.), Klinkend boeket: studies over renaissancesonnetten voor Marijke Spies (Hilversum: 1994) 143-149. The first remarks on the possibility of Lescailje's lesbian erotic feelings are made in Spies M., "Oudejaarsavond 1675: Cornelia van der Veer schaduwt Katharina Lescailje als deze van het huis van haar vriendin Sara de Canjoncle naar dat van haar zuster gaat. Het vrouwelijk aandeel", in Schenkeveld-van der Dussen M.A. (ed.), Nederlandse literatuur, een geschiedenis (Groningen: 1993) 282-285.

2 The poem, written on the occasion of the marriage of Sara de Canjoncle (I) and Nicolaas Buitendoor, is published in Lescailje Katharina, Tooneel- en mengelpoëzy, 3 vols (Amsterdam, Erfgen. Lescailje en Dirk Rank: 1731) II 16-18 (hereafter referred to as TMP). Gemert, "Hiding Behind Words?" translates parts of it.

${ }^{3}$ Grabowsky E., "Katharina Lescailje (1649-1711) en de 'vrouwenzucht': schijn of werkelijkheid?", Mededelingen van de Stichting Facob Campo Weyerman 23, 2 (2000) 65-79.
} 
witness to a discourse among independent businesswomen instead of a homoerotic discourse. The opposing stances in the discussion are interwoven with the critics' different perspectives; Van Gemert conducts a semiotic reading while Grabowksy's is biographical. Therefore, their interpretations will never meet in the middle, even though both critics do connect Lescailje's womanhood to the negative discourse on marriage in her poem.

This raises the question of how Lescailje's femininity is significant in her nuptial poetry. Lescailje wrote an enormous amount of nuptial poems, with at least ninety-seven known poems surviving. To my knowledge she was the first woman to participate so actively in this formerly male-dominated genre, which flourished in many European countries during the sixteenth and seventeenth centuries. The corpus of Lescailje's nuptial poetry is thus of particular relevance in addressing women's authorship. The case offers a unique opportunity to look at the appropriation of so-called male genres by women at the end of the seventeenth century.

Research into the differences between male- and female-authored literature is part of a feminist tradition of research into authorship from the perspective of the opposition between hegemonic and marginal social groups. ${ }^{4}$ Since men and women's social position and education differed, contrasts in their work are inevitable. Women authors have always needed to write themselves into existing genres that had moulded them, while they were neither able nor eager to completely adapt to them. ${ }^{5}$ This claim applies especially to the early modern period, as women at that time had a marginal position in public areas like literature. Moreover, social and literary conventions were relatively strict. A woman was not expected to write and publish, at least not outside of family circles. Should she still want to, she had to do it within the boundaries of the literary genres and boundaries established by male predecessors and contemporaries.

The question of female authorship is of the greatest importance with regard to the genre of nuptial poetry. ${ }^{6}$ During the early modern

${ }^{4}$ Cf. Miller N.K., "Changing the Subject: Authorship, Writing and the Reader", in Burke S. (ed.), Authorship. From Plato to the Postmodern: A Reader (Edinburgh: 2000) 194-195. 38.

${ }^{5}$ Meijer M., In tekst gevat. Inleiding tot een kritiek van representatie (Amsterdam: 1996)

${ }_{6}^{6}$ This specific question is asked in the introduction to the major Dutch anthology of women writers: Schenkeveld-van der Dussen R. - Porteman K. (eds.), Met en zonder 
period political and religious developments created social tensions surrounding various aspects of marriage, which resulted in a polemical discourse on marriage. ${ }^{7}$ As a part of the querelle des fermmes, women were demonised and men were advised against marriage because of the risk of being overruled by their future wives. ${ }^{8}$ During the seventeenth century, the opposition grew and in several texts of the period, marriage is also disparaged from the female perspective. ${ }^{9}$ Nuptial poetry is of course a genre in which this discourse is bound to play a role.

It is only recently that such suppositions have been given attention in research into the genre of nuptial poetry. Scholarly criticism has tended to neglect the insight that nuptial poetry reflected on society and participated in it, while it also exploited the range of possibilities that the variety of conventions allowed for. Whereas older research focused only on the literary aspects, today the social aspects are also being taken into account, as are the genre's great potential for adaptation. ${ }^{10}$ Heather Dubrow's study of the Stuart epithalamium is exemplary of this new approach. ${ }^{11} \mathrm{In}$ it, she examines the interplay between cultural tensions and the formal decisions that poets made in their work; she writes, 'Writing in a genre whose very conservatism made it appealing, Stuart poets often react to cultural tensions subtly, by emphasising or reinterpreting an existing convention'. ${ }^{12}$

A similar approach is required in investigating Lescailje's appropriation of the genre of nuptial poetry. How did a Dutch woman poet manage to appropriate the genre of nuptial poetry at the end of the seventeenth century, while dealing with both the possibilities and restrictions of the literary and social conventions she was exposed to?

lauwerkrans: Schrijvende vrouwen uit de vroegmoderne tijd 1550-1850. Van Anna Bïns tot Elise van Calcar (Amsterdam: 1997) 8.

${ }^{7}$ Dubrow H., A Happier Eden. The Politics of Marriage in the Stuart Epithalamium (Ithaca: 1990) 5-27. Carlin has several publications on this polemical discourse in France, including Carlin C.L., "Imagining Marriage in the 1690s", Papers on French Seventeenth Century Literature 28, 54 (2001) 167-176.

${ }^{8}$ Pleij H., "Taakverdeling in het huwelijk. Over literatuur en sociale werkelijkheid in de late middeleeuwen", Literatuur 3 (1986) 66-76 and "Wie wordt er bang voor het boze wijf? Vrouwenhaat in de middeleeuwen", De Revisor 4, 6 (1977) 38-42; DresenCoenders L., "De strijd om de broek. De verhouding man-vrouw in het begin van de moderne tijd (1450-1630)", De Revisor 4, 6 (1977) 29-37.

${ }^{9}$ Dubrow, A Happier Eden 20-25 and Carlin, "Imagining Marriage", 169-170.

${ }_{10}$ Blevins J., Catullan Consciousness and the Early Modern Lyric in England (Burlington: 2004).

${ }^{11}$ Dubrow, A Happier Eden.

${ }_{12}$ Dubrow, A Happier Eden xii. 
The present article aims to answer this question by giving an overview of the poems Lescailje wrote for different groups of addressees, focusing on her use of classical and - more importantly - contemporary conventions. Finally, I will compare Lescailje's nuptial poetry to that of other Dutch women poets. But before exploring these questions in greater depth, I will first introduce the genre and the author central to the present article.

\section{The Nuptial Poetry of Katharina Lescailje}

Sappho's poems as well as those of other classical authors deeply influenced the traditions of nuptial poetry in Renaissance Europe. ${ }^{13}$ These classical poems were called epithalamia, referring to folk songs shouted or sung by friends who led the couple to their bridal bed, just before the consummation of the marriage. In later times, however, the word epithalamium referred not only to songs spurring on the consummation, but also to the whole range of nuptial poems. The genre became very popular between the sixteenth and eighteenth centuries and was practised by many well-known poets in Europe.

In his Poetices libri septem (1561), the Italian scholar Julius Caesar Scaliger prescribed the rhetorical conventions for the epithalamium in the epical tradition of Claudian and Statius - as opposed to epithalamia of the Catullan lyrical tradition. Scaliger and other rhetoricians had great authority, but imitating predecessors and contemporaries seems to have been the common practice. ${ }^{14}$ Poets had several optional conventions at their disposal. The poets' freedom to select from a variety of conventions led to diverse applications, but the greater part of early modern nuptial poetry is fairly recognisable as such. ${ }^{15}$

${ }^{13}$ Tufte V., The Poetry of Marriage. The Epithalamium in Europe and Its Development in England (Los Angeles: 1970) describes the literary traditions in European epithalamia. If not otherwise stated, information on the genre in this section is from Tufte's book.

${ }_{14}$ This is argued in, among others, Schenkeveld-van der Dussen M.A., "Theorie en poëzie: een epithalamium van Six van Chandelier", De nieuwe taalgids 72 (1979) 391-398.

${ }^{15}$ See also Wheeler A.L., "Tradition in the Epithalamium", The American Fournal of Philology 51, 3 (1930) 205-223 and Babin M., Epithalamia: Classical Traditions and Changing Responses, PhD dissertation, University of California (1978) 172-173. 
The basis for the epic in nuptial poetry was often a (metaphorical) battle, in which the groom needed to capture the bride. Victory was celebrated when he was successful. Throughout the poem, the bride and groom were praised extensively, for example by reference to their families' achievements and wealth. The greater part of the praise, however, was directed to the bride's beauty and often included a tribute to her virginity. The poems could also include references to both pagan and Christian gods and unions - classical, biblical and faunal ones. The poems ended with the extension of congratulations and blessings, and also referred to the wedding night and the future offspring. However, as early as the classical period, something which might be characterised as an 'anti-epithalamium', which took a negative view to marriage, became discernible in the tradition of the epithalamium. This anti-epithalamium also has to be seen as part of the tradition. ${ }^{16}$

The genre of nuptial poetry flourished in the seventeenth-century Dutch Republic as it did in other European countries. The epical form of Statius and Claudian was dominant. At the end of the sixteenth century, it was exercised particularly by scholars writing in Latin. The writing of nuptial poetry in Dutch by famous learned poets such as Pieter Cornelisz. Hooft (1581-1647) and Joost van den Vondel (15871679) during the first half of the seventeenth century led to widespread publishing of nuptial poetry. The conventions of the genre changed, however. Whereas Hooft and Vondel had imitated the classical traditions in an original manner, in the second half of the seventeenth century, Christian aspects became more important than classical ones. ${ }^{17}$ Erotic tension regarding the wedding night was traditionally a reason for the bride to develop doubts about marriage as well as the cause of suggestive jokes. However, this had disappeared from nuptial poetry by the end of the seventeenth century. The dominance of the epical form diminished, too. The genre's reputation diminished among the cultural elite, but its popularity in society at large only increased..$^{18}$

16 Tufte, The Poetry of Marriage 37-55 and Dubrow, A Happier Eden 2.

17 In some of Vondel's poems Christian aspects were already dominant, but this was only the case in five of his more than fifty nuptial poems. See Schenkeveld-van der Dussen M.A., "Christus, Hymenaeus of de 'Teelzucht'", in Witstein S.F. - Grootes E.K. (eds.), Visies op Vondel na honder jaar. Een bundel artikelen ter gelegenheid van de driehonderdste sterfdag van foost van den Vondel (The Hague: 1979) 11-25.

${ }^{18}$ On the genre of nuptial poetry in the Dutch Republic see, in addition to Schenkeveld-van der Dussen, "Theorie en poëzie" and "Christus, Hymenaeus", also her 
Lescailje's participation in the genre of nuptial poetry reflects these developments.

Katharina Lescailje was a remarkable figure on the Amsterdam literary scene. ${ }^{19}$ She was the second daughter of the well-known publisher and poet Jacob Lescaille. Since he was the main publisher for stage plays and was well acquainted with many Amsterdam poets, it is likely that she had been in artistic circles since early childhood. Since the 1720s, the story has gone that when she was eleven years old, the uncontested patriarch of Dutch poetry, Joost van den Vondel, read some of her first poems and encouraged her to become a poet. Whatever the truth value of this story, Lescailje did become a poet. She wrote many poems, some of which were published. She also translated over seven tragedies, six of which were performed at the town theatre and were also published. ${ }^{20}$ When her father died in 1679, Katharina Lescailje took over the publishing house with her younger sister Aletta, who like Katharina, was unmarried. They kept the publishing house closely bound to the theatre and Katharina was able to publish her own works.

Lescailje moved in the circles of the Amsterdam cultural elite. Many of the occasional poems she wrote were addressed to fellow writers, both men and women. The amount of political poems she wrote, about twenty, is striking considering her position as a woman, but she hardly

articles "Vondel als gelegenheidsdichter en vriend. Het bruiloftsgedicht voor Ioan van de Poll en Duifken van Gerwen", in Eemeren G. - Willaert F. (eds.), 't Ondersoeck leert. Studies over middeleeurese en $17^{-}$-eeuwese literatuur ter nagedachtenis van prof. $d r . L$. Rens, (Leuven: 1986) 293-300; "Bruiloftsdichten in de tale Kanaäns: het probleem van de onverstaanbaarheid", De nieuwe taalgids 75 (1982) 50-60; "Hochzeitsdichtung und christlicher Glaube. Einige Epithalamien Niederländischer Dichter", Fahrbuch fir Internationale Germanistik A, 8 (1980) 31-37; "Een bruiloftsdicht van Karel van Mander", Tijdschrift voor Nederlandse taal- en letterkunde 92, 3-4 (1976) 189-202; "Bruilofts- en liefdeslyriek in de $18^{\mathrm{e}}$ eeuw: de rol van de literaire conventies", De nieuwe taalgids 67 (1974) 449-461. Strien T. van (ed.), Hollantsche Parnas. Nederlandse gedichten uit de zeventiende eeuw (Amsterdam: 1997) 49-51 pays attention to the genre too. Babin, Epithalamia 174-177 concludes that English nuptial poetry in later times also diverges more from classical traditions.

19 On Lescailje, zee Gemert L. van, "Katharina Lescailje (Amsterdam, 26 september 1649-Amsterdam, 8 juni 1711). Schrijfster annex uitgeefster", in Schenkeveld-van der Dussen R. - Porteman K. (eds.) Met en zonder lawwerkrans 396-402.

${ }^{20}$ One of Lescailje's plays is the subject of Oostrum P. van, "Dutch Interest in 17th- and 18th-century French Tragedies Written by Women", in Dijk S. van et al. (eds.), 'I Have Heard About You'. Foreign Women's Writing Crossing the Dutch Border: From Sappho to Selma Lagerlöf (Hilversum: 2004) 153-172. 
reflects explicitly on her participation in male genres. Moreover, Lescailje seems to quietly adopt most of the conventions upheld by literary men in her environment. Reception history shows how her position was regarded by others as exceptional. In their poetry, her colleagues exalted her as the 'Nederduitsche Sappho' (the 'Dutch Sappho') and she was asked to write opening poems for their own publications. They made a muse out of her. ${ }^{21}$

The collected works of Lescailje were published by her nephew in 1731, twenty years after her death, as Tooneel- en mengelpoëzy ('Dramatic and mixed poems'). The nuptial poetry is collected in a large section in the second volume called 'Huwelijkszangen' ('Nuptial songs'), with 96 poems. Many of them had been published before in separate publications or compilations of nuptial poetry. ${ }^{22}$ However, Lescailje must have written more nuptial poems than those 96 . In his foreword to her collected works, the publisher states that he did not want to include all of Lescailje's nuptial poems due to their great number and the fact that Lescailje herself had not been content with all of them. ${ }^{23}$ His apparent reserve at including all of her nuptial poems is somewhat strange as my own research has only uncovered one separately printed marriage poem by Lescailje that is not included in the collected works. ${ }^{24}$

Lescailje started writing nuptial poems for family and friends, and in the course of her career, she also began to write them for people she did not know as well. In this article I will argue that the way she makes use of the conventions depends to a large extent on who the addressee was. In the following sections, I will examine the nuptial poems Lescailje wrote for the different groups of addressees in a more or less chronological order: family members, literary contacts, patrons and Mennonite businessmen. Where possible, I will compare them to poems by other poets written on the same occasion.

${ }^{21}$ In a work in progress presented at a NEWW meeting, I made some preliminary remarks on the reception of Lescailje: Geerdink N., "Katharina Lescailje: Another Sappho", online: http://www.womenwriters.nl/index.php/Katharina_ Lescailje_\%281649-1711\%29:_another_Sappho or www.womenwriters.nl,Conferenc es $>$ NEWWNovembermeetings $>2007>$ Geerdink.

${ }^{22}$ References to all the publications of Lescailje's nuptial poetry can be found in appendix 1 below.

${ }_{23}$ Rank D., "Voorbericht", in TMP.

${ }^{24}$ Lescailje Katharina, in Op het huwwelyk van den heer Gerard Reessen, en jongkorouw Geertruid van der Keere. Getrouwd den viii. van Zomermaand, 1698 (Amsterdam, Erfgen. J. Lescailje: 1698). 


\section{Family}

The first of Lescailje's surviving nuptial poems dates from 1673. It seems she did write some more in the years that followed. Like her other early poems, those first few nuptial poems are addressed to people she was closely acquainted with, in most cases through her father. The first of Lescailje's nuptial poems published separately was written on the occasion of her older sister's wedding in December $1674 .{ }^{25}$ The poem is fairly conventional, including the groom's conquest to win the love of the shy and embarrassed woman, a good deal of praise and several puns with names. Nevertheless, it is still a personal poem. Lescailje focuses in this poem not on Matthias de Wreedt, the German printer her sister Barbara was going to marry, but on the bride and Lescailje's relationship with her. It leads to a lot of praise for Barbara Lescailje, who is said to be upright, to have a good reputation and to be modest and beautiful.

The praise is fairly conventional - although it focuses on more than the bride's' beauty - but in proportion to the praise for the bridegroom, it exceeds the conventions by far. The same is true of the congratulations at the end of the poem, which are fairly extensive and connected to the sisterly love between bride and poet. Lescailje starts by showing her sisterly duty to wish Barbara all the best:

Paste 't ooit verëende menschen

Heil en voorspoed toe te wenschen,

't Voegt en vloeit nu in myn dicht,

Scherp genoopt door zusterpligt.

If ever it fitted to wish united people

Welfare and prosperity,

It does so now and flows in my poem,

Powerfully prompted by sisterly obligations.

In the following verse, Lescailje emphasises the fact that Barbara will be leaving her home and her younger sister behind. Moreover, she refers to the myth of Procne, whose tongue was cut off by the husband of her sister Philomel, to whom she was very close. The unusual

${ }^{25}$ Published in Huwelykszangen, Ter Bruilofte van de E. Bruidegom Matthias de Wreedt, en de E. Bruidt Barbera Lescailje. In d'Echt verbonden te Amsteldam, den $8 / 18$ van Wintermaand, 1674 (no publisher, no date), and in TMP II 8-11. This is the only known nuptial poem Lescailje wrote for a member of her own family. 
reference would not have been very flattering to the future husband Matthias de Wreedt, but it reveals Lescailje's sincere concern for her sister's (and her own) future happiness.

The personal perspective also influences Lescailje's self-representation. By representing herself as the younger sister of the bride, the audience is invited to excuse Lescailje for writing and publishing a poem in the first place. It may thus have functioned as a topos of modesty to refer so extensively to sisterhood, which would have been considered relatively appropriate subject matter for women writing in family circles. At the same time, as a poet, Lescailje did not present herself modestly at all by displaying her ability to alter the traditional conventions in a learned manner - such as the use of the uncommon mythological reference. Moreover, as a consequence of Barbara and Katharina's personal connection, it could be argued that the praise in the poem could also apply to Katharina. One compliment supports this interpretation very clearly: Barbara is said to be 'zo teêr als goed gebooren' ('born both tender and honest'). The connotation is, of course, that the same goes for Katharina, who was after all born of the same parents. In presenting herself as the younger sister, ready to follow Barbara, Katharina was in fact even placing herself on the matrimonial market:

\author{
Zuster, die my in het paaren \\ Voortreed, als in tal van jaaren, \\ En om d'Echt, den Maagdestaat, \\ My, en 's Vaders huis verlaat; \\ The sister, who in pairing off \\ Precedes me, as she does in age, \\ And who, because of Wedlock leaves \\ Her Virginity, me, and our Father's house;
}

Because of this self-representation, the identity of the audience is particularly relevant. Lescailje's poem was published in a booklet alongside poems by her acquaintances from the theatre networks of the publishing house. With the exception of two other women poets, Cornelia van der Veer and Suzanna Bormans - both friends of Lescailje and probably of Barbara at the time - the poets represented in the booklet were young males who would later write plays and become important figures in theatre networks. In addition to her family, those networks made up the broader audience for the poem, while at the same time, the other poems create a frame of reference. 
What are the similarities and dissimilarities between Lescailje's poem and those by the other male and female authors ${ }^{26}$ The compilation opens with the three contributions by women, among which are more dissimilarities than similarities. Lescailje's is the only poem that complies with at least some of the rhetorical conventions of the genre. Suzanna Bormans's poem, the second in the booklet, is very short. ${ }^{27}$ It focuses on a conventional theme of the epithalamium - Matthias de Wreedt's patience - but the poem's structure does not resemble classical epithalamia at all. The first poem, by Cornelia van der Veer, is more extensive. ${ }^{28}$ It is a Christian poem with many (biblical) metaphors. Matthias de Wreedt's victory in winning Barbara's love is represented as a victory of God. That Van der Veer does not conform to the rhetorical conventions is explicitly stated in the middle of the poem:

Soo 'k nu een slaghveer kon den Mantuaan ontlenen,

Om 't kostlijk Paar naer eysch te ontmoeten op het Feest,

Dan soud myn sangheldin mé schoeyen op den leest

Der Konstgenoten, myn hoogdravende Mecenen;

Diens klancken met Katrijn, weêrgalmen aen het Y,

[...]

Maar laas! die pogingh is vergeefs my t'onderwinden,

Ik stoof myn sangen best met eygen saus en kruyt,

En schaf dien schótel op, voor Bruydegom en Bruydt,

Were it possible to borrow a quill feather from the Mantuan,

To treat the glorious Couple, true to the splendour of their feast,

Then my muse would follow the same pattern

As Fellow artists do, my grandiloquent Maecenas;

Whose sounds together with those of Katrijn, reverberate across the IJ-river,

$[\ldots]$

But alas! for me it is vain to make this endeavour,

I stew my songs best in my own sauce and spice,

And serve this dish, for Bridegroom and Bride,

${ }^{26}$ I do not address the difference in tone here. It is not surprising that the personal tone of Lescailje is unique in this booklet, since she is the one most closely connected to the bride. Nevertheless, other poems reveal references to some kind of personal commitment too.

${ }^{27}$ Suzanna Bormans married the famous poet Joannes Antonides van der Goes 4 years later, see below. Little is known about her poetry.

${ }_{28}$ On Cornelia van der Veer: Gemert L. van, "Cornelia van der Veer (Amsterdam, 30 augustus 1639-? na 10 april 1702). Amsterdams initiatief voor publicatie van eigen werk", in Schenkeveld-van der Dussen R. - Porteman K. (eds.), Met en zonder lauwerkrans 354-362. 
Van der Veer creates a contrast between herself and the other poets in the booklet, and the contrast with Katharina (Lescailje) is most explicit. Those 'konstgenoten' ('Fellow artists'), she states, write poems in the rhetorical tradition of classical authors like the Mantuan, i.e. Vergil, whereas she makes her own 'mash'. Nonetheless, by making this contrast she shows her familiarity with those traditions.

Cornelia van der Veer is right: Lescailje's poem bears more resemblance to the male-authored poems in the booklet than the other poems by women. Most of the poems following the three female-authored poems belong, at least thematically, to the classical tradition. The conquest of the bride is central, classical gods must interfere and in the end the poems refer to the wedding night and posterity. War and peace are referred to in most of the poems analogously to conquest and marriage. Both Lescailje and the later theatre director Joan Pluimer open with such a comparison, stating that they, in times of war, will focus on the peaceful love between Barbara and Matthias.

However, there are also differences between Lescailje's poem and the male poets' poems. The playfully erotic hints in some of the maleauthored poems are absent in Lescailje's poem. I assume this is motivated by social conventions. The difference in their descriptions of the bride's initial refusal is more interesting. The conventions prescribe initial hesitation for the woman, mostly connected to shyness, shame and anxiety regarding the wedding night. Lescailje adds the loss of freedom the bride accepts when entering into marriage. She introduces a relatively negative discourse on marriage that is not present in the other poems, and is even refuted in the Pieter de la Croix poem, which argues that virgins who reject marriage fail to recognise or respect the importance of love.

We know that with its polarisation of marriage and freedom, Lescailje's negative discourse nevertheless returned in other nuptial poems. Here it is suited to the sisterly tone: while on the one hand it seems that Lescailje does not want her sister to abandon her, on the other hand it seems that she is fervently hoping that her sister will have a happy marriage with her future husband. The negative discourse also relates to Lescailje's representation of herself as a woman who still has her independence. Despite this difference between the poems by Lescailje and the male-authored poems in the booklets, it is important to acknowledge how Lescailje still adheres to the mainly male conventions of the genre, even on a family occasion. 


\section{Cultural Networks}

Many of the acquaintances to whom Lescailje addressed nuptial poems were people from her cultural networks: the Amsterdam literary scene and its elite circles as well as relatives connected to through the publishing house and theatre world.

In the seventies, Lescailje wrote some nuptial poems for female friends she knew through these cultural networks. ${ }^{29}$ In them, she wrote extensively about the yoke of marriage and the restrictions it would place on the freedom of women. An extremely negative example is the aforementioned poem for Sara de Canjoncle (1677) in which Lescailje emphasises her personal relationship with the bride by focussing on her instead of her future husband and also by calling her 'myne Speelgenoot' ('my companion'). ${ }^{30}$ The same goes for the poem on the marriage of Suzanne Engelbrecht and Abraham van Koppenol (1673), in which the praise for Engelbrecht exceeds the praise for Van Koppenol many times over. Moreover, Lescailje represents herself in this poem as writing with the 'maagdepen' ('pen of a virgin'), which focuses on marriage rather than on war as the pens of men do. ${ }^{31}$ By referring to herself as a virgin, Lescailje simultaneously links herself to Suzanne Engelbrecht, whose virginity is mentioned several times in the poem, and to a larger group of honourable women possessing that same virginal moral strength.

The anti-marriage discourse in these poems has the same dual function as in the poem for her sister's wedding. The emphasis on how the friends are abandoning Lescailje by marrying foregrounds her personal commitment. But, at the same time, the discourse can be interpreted as part of Lescailje's self-representation as a poet. Unmarried, she is still free and independent and therefore has all the time in the world to, for example, write poems. This interpretation is supported

${ }^{29}$ I refer here to the poems for Suzanne Engelbrecht, Sara de Canjoncle, Suzanna Bormans and Maria Wiebouts, published in TMP II 3-7, 16-18, 19-22, 81-84. Suzanne Engelbrecht is said to sing beautifully in the poem. Sara de Canjoncle was the cousin of the two poets Sara de Canjoncle (II) and Jan de Canjoncle. Suzanna Bormans wrote poetry herself and later married Joannes Antonides van der Goes. Maria Wiebouts, who also wrote poetry herself, had been married to the savant Joan Blasius.

${ }^{30}$ On the negative discourse in this poem, see Gemert, "Hiding Behind Words?" and "De vrouwenzucht".

${ }^{31}$ In the meantime, Lescailje did write poems on the ongoing war. Therefore, the contrast between her and the male poets can best be read as a topos (of modesty). 
by poems for other (male and female) poets who were well-known and respected in the Dutch Republic, or at least in the province of Holland. In those poems, Lescailje represents herself as woman of letters, as the focus is more on literary networks and less on the personal aspect, although in most cases there must have been some kind of friendship between Lescailje and the poet addressees.

An early example is the poem Lescailje wrote for her friend Suzanna Bormans's marriage to the famous poet Joannes Antonides van der Goes in 1678. It is the opening poem of a booklet with nuptial poems by several poets - all men except for Lescailje. ${ }^{32}$ The focus in Lescailje's poem is on Antonides van der Goes. The bride is praised extensively, but Lescailje attends to the future husband. This is part of Lescailje's self-representation as a poet.

The poem differs significantly from Lescailje's other nuptial poems. In this poem, there is no conquest. Van der Goes does not need to win Bormans's love. The poem is presented as a description of the wedding celebration and focuses on the poems written to celebrate it:

Apollo komt uw Echt bekroonen,

En noopt de Dichters tot uw lof;

Zy zwemmen in een zee van stof,

Nu de allerwaardste van zyn Zoonen,

Naar zyne godheid best geäard,

Met een der Zanggodinnen paart,

Apollo will reward your [Antonides's] Wedlock,

And prompts the Poets to sing your praises;

Afloat a teeming sea of material,

Now the most valuable of his Sons,

Best resembling his deity,

Couples with one of the Muses,

Lescailje states here how 'de Dichters' ('the Poets') all praise the bridegroom, without identifying who these poets are. Since she also leaves implicit how she herself relates to the poets, the reader is subtly led to think of her as a member of that group of poets. After all, Lescailje praises Antonides van der Goes in a literary manner, in the foregoing and following lines. The supposition that Lescailje belongs to the

32 Ter bruilofte van den heere foannes Antonides van der Goes, der Medicïnen doctor, en mejuffrouw Suzanna Bormans (Rotterdam, Abraham van Waesberghe: 1678). 
group of literary poets is maintained throughout the poem. She writes for example:

$\mathrm{Nu}$ strooit het kunstenkweekend Y

Een vrucht'bre lent' van Poëzy,

Cultivating the arts, now the IJ

Strews forth a fruitful spring of Poetry,

The poems for the wedding originate in the city of Amsterdam (the IJ is an important river in Amsterdam), Lescailje's hometown. Later on, the river running through Antonides van der Goes's hometown, Rotterdam ("De Maasstroom", 61), is also mentioned, but the Amsterdam poetry is mentioned first and most extensively. In the last part of the poem, Lescailje reemphasises her own membership in the group of poets by extending the traditional wish for offspring on behalf of the 'Zangberg' (Parnassus):

De Zangberg is reeds in verlangen,

En ziet uit uwen Echt te moet

Een Vrucht, die volg' zyn vaders voet,

En 't Spoor van uwe Heldezangen.

Mount Parnassus is already longing,

And looks forward to the Issue of

Your Wedlock, that must follow in his father's footsteps,

And the trail of your Heroic song.

The other poets in the booklet also focus on Antonides van der Goes and emphasise the literary status of bride and groom. However, the representation of their own poethood is more explicit. Moreover, in the male-authored poems more references are made to literary (net) works. Shortly before the wedding, Antonides van der Goes had broken with the important literary society Nil volentibus arduum. This rift is mentioned and commented on in various poems. Most poets seem to prefer, like Lescailje, the literary themes to the traditional conventions of the nuptial poem - except for the conventional extension of wishes for (literary) offspring and the inclusion in some poems of a description of the conquest.

Remarkably, in two of the poems the conquest depicted is not the groom's conquest of the bride, but Love's conquest of Antonides van der Goes. Joan Pluimer and David van Hoogstraten speculate that Antonides van der Goes has been talked into love. They fear his literary activities may cease and Pluimer even talks of the marriage as 
a prison and a disaster for the bridegroom's freedom. In this way it approximates Lescailje's anti-marriage discourse while retaining the perspective of the man, upon whom, it seems, marriage made less of an impact than on the bride. Why should Antonides van der Goes stop writing poems after marrying? This suggests that the reversal and exaggeration of the topos gave the poets the opportunity to emphasise Antonides van der Goes's worth as a poet.

Lescailje, however, seems to avoid this discourse in the poems she composed for famous male poets, ${ }^{33}$ whereas she used it in poems for celebrated female poets. At least this is the case in the poem she wrote on the occasion of the marriage of the Haarlem poet Elisabeth Hoofman, to Pieter Koolaert in $1693 .^{34}$ In this poem Lescailje again emphasises her literary connection to the poet - the bride in this case and she represents herself as a woman of letters as she did in the poems for male colleagues. But in this poem for a female colleague, Lescailje also wonders why the bride decided to marry and in so doing give up the laurels she had gained through her literary activities. Lescailje composed this poem more in keeping with the conventions of the genre. This is clear from the extensive depiction of the conquest; Elisabeth Hoofman had taken some convincing to accept the proposal of marriage. The use of the anti-marriage discourse, however, can be read as part of the representation of Lescailje's own poethood, an interpretation I have already advanced in the analysis of earlier poems for female literary friends. With this poem, Lescailje created an image of herself as an unmarried woman, able to put all of her time into poetry and gaining laurels, as opposed to the soon to be married Elisabeth Hoofman. It is therefore significant that the other poets

${ }^{33}$ Cf. the poem Lescailje wrote several years later (1685) for a poet with a comparable position in literary circles, David van Hoogstraten, published in Parnaskranssen gevlogten op het Huwelijk van den Heere David van Hoogstraten, Der Medicinen Doctor, en Mejuffrou Maria van Nispen. Voltrokken te Dordregt den 28. Van Lentemaend 1685 (Dordrecht, Jan van Hoogstraten: 1685) and in TMP II 59-61.

${ }^{34}$ This poem was published in Op het Huwwelyk van den Heer Pieter Koolaert, En Mejuffrouw Elizabeth Hoofman. Getrouwd in Haarlem, den 23 van Oegstmaand, 1693 (Amsterdam, Erfgen. J. Lescailje: 1693) and in TMP II 114-120. On Elisabeth Hoofman: Strien T. van, "Elisabeth Hoofman (Haarlem, 23 februari 1664-Kassel, 4 juli 1736). Dichterlijke documenten uit een veelbewogen leven", in Schenkeveld-van der Dussen R. Porteman K. (eds.), Met en zonder lauwerkrans 441-444. Another example is the poem for Juliana van der Schelling (1695, published separately and in TMP II 143-149), a learned poet who apparently translated Ovid. We know very little about her, so her literary status is less clear than the status of Elisabeth Hoofman. 
who wrote nuptial poems for Elisabeth Hoofman, including David van Hoogstraten and Joan Pluimer, scarcely mention this topic, whereas they did mention it in the poems for Antonides van der Goes, a poet of their own sex.

In conclusion, it can be said that the nuptial poetry Lescailje composed for members of her literary circles aimed at strengthening bonds - those with other female writers by emphasising their (former) freedom and those with (famous) male poets by emphasising shared poethood. Moreover, the poetry served as a platform for Lescailje's self-representation as a poet - not only by connecting herself to other poets, but also through the focus on poetry, (her own) poethood and the representation of herself as a free woman with time for literary activities.

\section{Patrons}

Lescailje's nuptial poetry includes several poems for people with a presumably higher social status than her own. I will refer to them as 'patrons', although I am not completely sure what the precise character of their relationship with Lescailje was. The generally acknowledged definition of patronage comprises three elements: a relationship of patronage is a reciprocal, personal and long-term relationship between two asymmetrical parties. ${ }^{35}$ For the people addressed in the nuptial poetry central to this section, at least two of the three elements of patronage are present. ${ }^{36}$ They lived and worked in a higher social stratum than Lescailje did. Since Lescailje addressed them not only in nuptial poems, but also in other poems written over a longer period which in many cases reveal personal interaction between them such as visits, the personal and lasting bond is also accounted for. What I cannot judge is the reciprocity of these relationships. There is little proof of exchange of capital between Lescailje and those who I suppose were patrons, except for the poems themselves and the mentions of visits. The poetry does however intimate that some kind of reciprocity was likely.

${ }^{35}$ This definition can be found in, for example, Nauta R.R., Poetry for Patrons: Literary Communication in the Age of Domitian (Leiden: 2002).

${ }^{36}$ Most evidently, this is the case in poems for members of the families Amya, Blaeu, Van Zon and Smids. 
A first set of poems for patrons are the nuptial poems written for members of the Blaeu family. As fellow printers, the Lescailjes and the Blaeus were closely connected. The interaction between Katharina's father Jacob Lescailje and the elder Joan Blaeu (1596-1673) in particular must have been fairly intense. One of Katharina's stepbrothers, Joan van Dorsten, had also worked for the Blaeu company. Unlike Jacob Lescaille, Joan Blaeu was famous all over the world because of his atlases, and several members of his family held government jobs in the city of Amsterdam ${ }^{37}$ Katharina Lescailje wrote nuptial poems for some of Joan Blaeu's children, who all married members of the Amsterdam governmental elite..$^{38}$ Although these children were part of Lescailje's generation, the poems exhibit a remarkably distant admiration. The personal connection between author and addressee or the fact they had the same profession is not mentioned at all. The Blaeu descendant, male or female, stays at the centre of each poem and is given great praise, either for his or her artistic, scientific or governing merits, which were said to contribute to the fame and prospects of the city of Amsterdam. The traditional conquest is only dominant in the poem for Louize Blaeu, although her doubts about marriage stem not from the typical causes of fear and shyness, but from the impending loss of her artistic and scientific occupations - a fainter version of the anti-marriage discourse. The same is said in the poems for the male Blaeus - a reversal of the traditional conquest. Paradoxically, the Blaeu children's occupations and their government jobs are also used as arguments to convince them to marry. They must pass down their merits to posterity for the sake of Amsterdam. Lescailje thus again adapts the conventions of the genre to suit the aim of the poems, namely, to express great admiration for the Blaeu family.

This is also the case in the nuptial poem Lescailje wrote for Willem van Zon and Helena van der Hek in $1687 .{ }^{39}$ In this poem, however, the reversal also accounts for the consolidation of Lescailje's relationship with her patron. Willem van Zon (1653-1713) descended from a

${ }^{37}$ Donkersloot-de Vrij M., Drie generaties Blaeu: Amsterdamse cartografie en boekdrukkunst in de zeventiende eeuw (Zutphen: 1992) 45-47. Grabowsky, "Katharina Lescailje" 74 states that Joan van Dorsten worked for the Blaeu family.

${ }^{38}$ She wrote poems for the weddings of Joan Geerkens and Louize Jakobe Blaeu (1676, TMP II 12-15), Joan Blaeu jr. and Eva van Neck (1679, TMP II 23-26), and Pieter Blaeu and Geertruid Alewyn (1690, TMP II 99-104).

${ }^{39}$ TMP II 66-70. Lescailje wrote a second poem on the same marriage on behalf of Maria Barnsteen, Van Zon's maid (TMP II 71). 
Rotterdam family which had made its fortune in the Baltic Sea trade. He lived in Utrecht, where he was 'Domheer van Oudmunster', an honourable profession only practised by city dignitaries. ${ }^{40}$ Lescailje wrote many poems for Willem van Zon and after 1687, also for his family. The poems refer to Van Zon's interest in Lescailje's literary activities and a close relationship between him and the poet. Lescailje emphasises this connection in his nuptial poem:

Zou myne Zangmeestres, in zo veel plechtigheden

En uitgelaaten vreugd, niet mee ten reyë gaan?

En in uw bruiloftspalm, laurier en mirtheblaân

Haar vaerzen mengen, om door uwe min te leeven?

$\mathrm{O}$ ja! Zy voelt haar van uw vriendschap aangedreeven,

En, door uw huwlykstoorts bescheenen en verlicht,

Zingt zy, in schaduw van uw liefde, haar gedicht.

Why would my Muse, in so many ceremonies

And such exalted merriment, not join in the chorus?

And to your bridal palm, laurel and myrtle,

Add her verses in order to live through your love?

O yes! She feels urged by your friendship,

And, enlightened and illuminated by your marital torch,

She sings, in the shadow of your love, her poem.

This emphasis on a personal relationship with a man is highly unusual in the nuptial poetry of Lescailje. In the reversal of the conquest following the introduction, the relationship is stressed again implicitly. Lescailje argues that Van Zon had not wanted to marry previously because he was already in love, with his freedom. Van Zon is portrayed as having achieved wisdom in his 'boekvertrek' (study) where he was engaged in practising literature. With this reversal of the antimarriage discourse, Lescailje implicitly refers to her own activities and what they signify to Van Zon.

In other nuptial poems for patrons, such as the one for the rich Hermannus Amya, who was in the theatre business, and the one for the woman believed to be his sister, Lescailje does not emphasise her personal relationship with the addressees very much, but she is less distant here than in the poems for the Blaeus. ${ }^{41}$ Apparently, Lescailje had

${ }^{40}$ On the profession of Van Zon: Hoven van Genderen B. van den, De heren van de Kerk. De kanunniken van Oudmunster te Utrecht in de late Middeleeuwen (Zutphen: 1997).

${ }^{41}$ The poem for Harmannus Amya and Catharina Vogelaer is published in TMP II 41-46, and in the booklet Op het huuwelyk van den heer Harmannus Amya, en jongkvrouw Catharina de Vogelaar. Getrouwd in Amsterdam, den 19 van Wijnmaand 1683 (no publisher, 
different relationships with these people and the nuptial poems were adjusted to suit the relationship. This is also clear from poems by other poets - all connected to the Amsterdam theatre world and appreciated in literary networks - written to celebrate Hermannus Amya's marriage. The degree of intimacy in their poems differs greatly, as does the description of the conquest. In the poems in the booklet, the descriptions range from absent to very present, and the focus varies from bride to groom or both. In her poem for Harmannus Amya, Lescailje describes how both bride and groom needed to be convinced by Love, because they were otherwise occupied and loved their freedom. The negative discourse on marriage in the poems for patrons is used to expand the ways in which she can praise them or strengthen her relationship with them. These reasons were apparently important enough for her to make the discourse work both ways, since Lescailje describes the loss of freedom for grooms too - something she avoided in the poems for male poets.

\section{Commissioned Nuptial Poems}

About a third of Lescailje's marriage poems is addressed to members of networks of Mennonite businessmen who lived in Amsterdam and Haarlem. These poems were written between 1685 and 1708. It seems that scarcely any of these Mennonites played an important role in Lescailje's own networks, since she did not write anything other than nuptial poems for them and there is no other evidence of a close relationship between them. Moreover, other people who wrote poems for the same Mennonite merchants, sometimes in the same booklets as Lescailje, were not the poets we normally encounter in Lescailje's (net)works. For this reason, it does not seem very plausible that Lescailje wrote poems for this group in order to obtain or consolidate social contacts. Why then, did she write such a large amount of nuptial poetry for Mennonite businessmen?

no date). The poem for Anna Rebekka Amya and Carel Hartsingh only survived in TMP II 35-40. On Hermannus Amya see Winkel J. te, De ontwikkelingsgang der Nederlandsche letterkunde V (Haarlem: 1924) 487, 492, 494; Kooijmans L., De doodskunstenaar: de anatomische lessen van Frederik Ruysch (Amsterdam: 2004) 218; Sterck J.F.M., Uit het Amsterdamsche tooneelleven op het einde der xviie eeuw (Leiden: 1913). 
The reason has to be a financial one. ${ }^{42}$ A group of Mennonites had become very wealthy in the second half of the seventeenth century. ${ }^{43}$ Their wealth revealed itself for example in the extravagant festivities they organised in honour of marriages and the important role that collections of nuptial poetry played in those festivities, as they were distributed among the guests. ${ }^{44}$ The bridal couple's prestige was increased by gathering as many poems as possible. The poems were often written by family or friends who were not known as poets. Occasionally though, more or less famous poets were also asked to write a poem; the more famous the poet, the better it was for the reputation of the bridal couple. ${ }^{45}$ Lescailje wrote more nuptial poems for Mennonite circles than any of her fellow Amsterdam poets, and her poems were almost always first in the collections. Although receiving money for poems was not that normal at the end of the seventeenth century and there is no proof of payments made by Mennonite businessmen to Lescailje, it is probable that she made money from the commissions by

42 'I have elaborated the following argument in Geerdink N., "U vraagt, wij draaien? De huwelijksgedichten van Katharina Lescailje (1649-1711) voor rijke doopsgezinden" to be published in Doopsgezinde Bijdragen 35-36 (2010)'.

${ }^{43}$ On the assimilation of Mennonites in the Dutch Republic: Visser P., "Mennonites and Doopsgezinden in the Netherlands, 1535-1700", in Roth J.D. - Stayer J.M. (eds.), A Companion to Anabaptism and Spiritualism, 1521-1700 (Leiden - Boston: 2007) 299-345; Visser P., "Aspects of Social Criticism and Cultural Assimilation: The Mennonite Image in Literature and Self-Criticism of Literary Mennonites", in Hamilton A. - Voolstra S. - Visser P. (eds.), From Martyr to Muppy. A Historical Introduction to Cultural Assimilation Processes of a Religious Minority in the Netherlands: the Mennonites (Amsterdam: 1994) 67-82; Welcker J.M., "Het dagelijks brood. De doopsgezinden, de economie en de demografie", in Groenveld S. - Jacobszoon J.P. - Verheus S.L. (eds.), Wederdopers, menisten, doopsgezinden in Nederland 1530-1980 (Zutphen: 1980) 195-218.

${ }^{44}$ On the extravagant festivities see Visser, "Aspects of Social Criticism" 76. Remarkably, there has thus far been little attention paid to the nuptial poems written for the wealthy Mennonites. The most important source seems to be Smit K., Pieter Langendijk (Hilversum: 2000) 51, 138-140, 198. However, it is easy to find enormous amounts of nuptial poetry for Amsterdam and Haarlem Mennonites through a catalogue search of occasional poetry: Bouman J., Nederlandse gelegenheidsgedichten voor 1700 in de Koninklijke Bibliotheek te 's-Gravenhage: Catalogus van gedrukte gedichten op gedenkwaardige gebeurtenissen in het leven van particuliere personen (The Hague: 1982); Daamen M. - Meijer A., Catalogus van gedrukte Nederlandse gelegenheidsgedichten uit de zeventiende en achttiende eeurw in de Zeeuwese Bibliotheek te Middelburg (Middelburg: 1990); Steur A.G. van der, Catalogus 28: Gelegenheidsgedichten. Los verschenen gedrukte gelegenheidsgedichten op Nederlandse personen, 17e-20e eeuw (Haarlem: 2004). An overview of some Haarlem poems can be found in Nieuweboer A., "Haarlems literair leven in gelegenheidsgedichten (1680-1770)", in Grootes E.K. (ed.), Haarlems helicon. Literatuur en toneel te Haarlem vóór 1800 (Hilversum: 1993) 187-201 - she does not, however, problematise the Mennonite background of the bridal couple.

${ }^{45}$ See also Smit, Pieter Langendijk 139. 
printing the complete booklets. ${ }^{46}$ Not all booklets identify their printers, but when they do, it is clear time and again that the booklets for which Lescailje wrote the opening poem were printed by her own publishing house. This leads to the assumption that she gained printing commissions by offering to write nuptial poetry. How does this assumption influence the poems?

Lescailje's attitude in the nuptial poems she wrote for Mennonites is relatively in line with the conventional topoi. Both author and addressee are mostly absent. Lescailje does not use the first person much and does not refer to any personal connections between her and the bridal couple. The bridegroom is addressed in almost all of the poems, but we do not learn much about him or his bride - who is scarcely addressed in these poems, with the exception of the congratulations at the end of each poem, which are directed to the couple. Of course several references are made in praise of the bride and groom's virtuousness, as well as frequent remarks about how highly the groom values his diligence. Trade, therefore, is a dominant theme in many of these poems. The conventional praise reveals the distance between Lescailje and the bridal couple, in contrast to other poems where Lescailje makes clear her connection to the addressees or at least tries to create a connection.

Except for the praise, however, the poems Lescailje wrote for the Mennonite businessmen are not that conventional. In contrast to the conventions of traditional epithalamia, in the Mennonite nuptial poems the bridegroom encounters few difficulties in winning the bride's hand and as a consequence, marriage is represented in very laudatory terms. Love, given from God, is said to be the basis of everything, most importantly procreation, but also sociability. In this respect, these particular nuptial poems by Lescailje are more in the Christian-moralistic tradition of Cats and his imitators than in the tradition of the classical epithalamia, which was more dominant and more appreciated in

\footnotetext{
${ }^{46}$ More research into poetry and payment remains to be done, but generally, it is assumed that in the seventeenth-century Dutch Republic, it was not the custom to pay for poems. See Spies M., "Betaald werk? Poëzie als ambacht in de 17e eeuw", Holland. Themanummer Kunst in opdracht in de Gouden Eeuw 23 (1991) 210-224. Drees J., Die Soziale Funktion der Gelegenheitsdichtung. Studien zur Deutschsprachigen Gelegenheitsdichtung in Stockholm zwischen 1613 und 1719 (Stockholm: 1986) provides, however, some proof that in late seventeenth-century Sweden some poets were paid for their efforts.
} 
Lescailje's circles. ${ }^{47}$ In her other nuptial poems, the conquest is portrayed as being more fierce and the tone regarding marriage tends to be more negative. This may explain the frequency of lyrical passages in her poems for Mennonites and the relatively large amount of lyrical poems she wrote for them. Lescailje normally tended to write epical nuptial poetry, but for this group she wrote more lyric poetry.

Other people who wrote for the same Mennonite tradesmen, particularly male Mennonites whose poetic endeavours were focused on writing nuptial poetry ${ }^{48}$ wrote poems with a personal dimension. At least their focus tended to include the whole family instead of just the bride and groom. Grandfathers and fathers are addressed or presented as speakers in the poems. The future offspring are also praised extensively. This shows the poet's personal commitment to the bridal couple. This is further emphasised by a secondary focus on the wedding celebration, which the poets would have attended. However, the discourse about marriage and conquest can be compared to the discourse in the poems Lescailje wrote for Mennonites, although the poems of Mennonite male poets were more firmly rooted in a religious framework.

The comparison with other poems for the same addressees, written by Mennonites who were often part of the same networks as the bridal couple, shows how Lescailje conformed to the desired conventions of her audience and its social network. She could not give the poems much of a personal touch, but she did alter her discourse on marriage to suit the discourse practised by her audience. It seems that Lescailje simply prepared what she was commissioned to write.

${ }^{47}$ See Bornemann U., "Die Gelegenheitsdichtung am Beispiel der Hochzeitsdichtung", in Bornemann U. (ed.), Anlehnung und Abgrenzung. Untersuchungen zur Rezeption der niederländischen Literatur in der deutschen Dichtungsreform des siebzehnten Fahrhunderts (Assen Amsterdam: 1976) 182-191 on Cats's moralistic nuptial poetry. The use of predominantly Christian elements in nuptial poetry is a trend that emerged towards the end of the seventeenth century in the Dutch Republic. It is worth noting in this context that it was the Mennonite Karel van Mander who originated this trend in the Dutch Republic: see Schenkeveld-van der Dussen M.A., "Poëzie als gebruiksartikel: gelegenheidsgedichten in de zeventiende eeuw", in Spies M. (ed.), Historische letterkunde. Facetten van vakbeoefening (Groningen: 1984) 83; Schenkeveld-van der Dussen, "Christus, Hymenaeus" and "Hochzeitsdichtung".

${ }_{48}$ The most well-known is Anthony Janssens, father of the famous Antonides van der Goes. He wrote over 175 nuptial poems, cf. Daamen - Meijer, Catalogus 11-15. For more names of authors see the list of separate publications of marriage poetry in appendix 1 below. 
Yet there is one aspect of these poems which can be connected to Lescailje's self-representation. In some of the poems for Mennonite marriages, Lescailje extensively describes how brides or the mothers of the brides were self-employed - this was not normally the case in other poems, in which she scarcely pays attention to the life of the bride or her mother. ${ }^{49}$ The praise for these women can of course also be applied to Lescailje herself.

\section{Lescailje versus other Dutch Women}

The developments in the genre of nuptial poetry in the seventeenthcentury Dutch Republic described in the introductory section of this article could lead to the assumption that the genre gradually came more into women's reach. At any rate, there were no longer aspects of the genre that they were not able to adapt because of a lack of education or a threat to their honour and respectability. In addition, during the seventeenth century writing poetry became more and more a social activity and as such it was also practised by women, who started writing by appropriating social conventions. ${ }^{50}$ Since nuptial poetry and its growth were examples of this tendency, one would expect women to adopt this genre too.

And indeed, the number of women participating in the genre did increase in the Dutch Republic. Before, there had been exceptions such as Anna Bijns (1493-1575) $)^{51}$ and Anna Roemersdochters Visscher (1583-1651), ${ }^{52}$ but it was not until the last decades of the seventeenth century that more women began to participate in the genre. However, the number of women participating in the genre in fact remained relatively small: the amount of nuptial poems Lescailje wrote far exceeds that of other women. ${ }^{53}$

\footnotetext{
${ }^{49}$ See TMP II 95-98, 170-173; 187-191.

${ }^{50} \mathrm{Jeu}$ A. de, 't Spoor der dichteressen'. Netwerken en publicatiemogelijkheden van schrijuende vrouwen in de Republiek (1600-1750) (Hilversum: 2000) 32.

${ }^{51}$ Cf. Pleij H. (ed.), 't Is al vrouwenwerk. Refreinen van Anna Bïns (Amsterdam: 1987) 117-125. On Anna Bijns see also Porteman K., "Anna Bijns (Antwerpen, 1493 Antwerpen, 1575). De ster van de rederijkers", in Schenkeveld-van der Dussen R. Porteman K. (eds.), Met en zonder lauwerkrans 107-117.

${ }^{52}$ Cf. Jeu, 't Spoor der dichteressen' 195.

53 There seems to be no difference between the Dutch Republic and other European countries in this respect. It is of some significance that Schenkeveld-van der Dussen R., "Met en zonder lauwerkrans in an International Perspective", in Dijk S. van -
} 
I found twenty-two printed poems, written by eleven women in the period $1660-1720 .{ }^{54}$ The majority of the poems were obviously written for people the women knew, and it is rare for one woman to have written more than one or two poems that have survived. The amount of nuptial poetry Anna Maria Paauw wrote (seven poems) is thus exceptional. ${ }^{55}$ We have seen how for Lescailje, the nuptial poems had an important function in different respects, and led to specific adaptations of classical and contemporary conventions. How do nuptial poems by other women relate to Lescailje's?

I have already mentioned that Suzanna Bormans wrote a short and not very ambitious poem for Lescailje's sister, while on the same occasion, Cornelia van der Veer explicitly dissociated herself from the conventions among male poets. In a second poem by Cornelia van der Veer, written in 1676, she again sets herself apart from authors who wrote traditional nuptial poems. Van der Veer wonders at the start of the poem who she can ask for inspiration, only to answer herself that she in any case does not want to ask a pagan god to inspire a poem

Gemert L. van - Ottway S., Writing the History of Women's Writing. Toward an International Approach (Amsterdam: 2001) 239-250 in a comparison of literature by seventeenth-century women from different European countries, does not mention the genre. Dubrow mentions only Katherine Philips (1632-1664) as an English woman poet of epithalamia: Dubrow, A Happier Eden x. Other publications on English nuptial poetry also only sporadically mention women: Tufte V., High Wedlock Then Be Honoured: Wedding Poems from Nineteen Countries and Twenty-Five Centuries (London: 1970) 87 mentions Anne Bradstreet (ca. 1612-1672), who wrote a poem for her husband. Babin, Epithalamia 186 mentions a satirical nuptial poem by Mary Wortley, Lady Montagu (1690-1762). Case R.H., English Epithalamies (London: 1896) lvii mentions Susannah Centlivre, who wrote a nuptial song in 1711 .

${ }^{54}$ See appendix 2 for the entries of the nuptial poems by women. I left out possible handwritten nuptial poems by women that functioned in the familiar context of the marriage of friends or family. I thus only counted poems printed separately or in a booklet of nuptial poems. Katharina Johanna de With published some more nuptial poems along with her pastoral plays, but since we do not know whether those poems were printed on the occasion of the wedding, I regarded them as handwritten. They are to be found in With K.J. de, Fillis van Scirus, herdersspel (Amsterdam, Adriaan Wor and Erven G. Onder de Linden: 1728) and With K.J. de, De getrouwe herderin (Rotterdam, Arnold Willis: 1719). I found one poem that only exists in manuscript. It is by Elizabet Senten and was written for her mother's wedding in 1690. It is a short poem by a supposedly young daughter in which she promises to accept her mother's new husband as a new father. She also emphasises her filial obedience. The poem is in handwriting on the back of Houwlykslof. Ter bruilofte van Theodorus van Born, met Maria vander Schuuren (Amsterdam, Dirk Boeteman: 1690) [PBZ Gel. Ged. 133]

${ }_{55}$ On Anna Maria Paauw: Jeu, A. de, "Anna Maria Paauw (Den Haag ? - Gouda, 21 oktober 1710", in Schenkeveld-van der Dussen R. - Porteman K. (eds.), Met en zonder lauwerkrans 431-435. 
for this 'heavenly' marriage. Indeed, the poem does not refer at all to any classical myths but to biblical stories and persons instead. It is a Christian poem, although Van der Veer does comply with some of the conventions of the epithalamium, such as the bride's doubts (because of her purity) and the reference to future generations at the end of the poem. Van der Veer's poem resembles the poems by Neeltje Beths. ${ }^{56}$ Beths also wrote only Christian poems in which she explicitly rejected pagan traditions.

Unlike Van der Veer, Beths only wrote poems addressed to family. She makes this familiarity explicit in the poem she wrote for her son's wedding in 1696. References to the personal relationships between the poet and the bride or groom also occur in the poetry of Anna Insma de Bruyn, Sara Kopyn, Katarina van Meersch and Paschyna van Mazeik. Implicitly, the family relationships are the exceptional reason that these poems were composed. In the poem by Paschyna van Mazeik, of whom nothing is known apart from this poem, the familiarity between author and addressee is particularly salient:

Om myn genegentheid aan $\mathrm{u}$ te laten blyken,

Eerwaarde Nicht, moest ik uw bruiloftsfeest verrijken;

Gelijk men voor de bruid de beste schotel zet,

$\mathrm{U}$ toetedienen met myn beste dichtbanket.

As a token of my affection for you,

Dearest Cousin, I had to enrich your wedding feast;

Just as one serves the bride the best dish,

It behooves me to serve you my best poetry banquet.

There is one poem in which references to either personal contacts or the classical tradition are wholly absent. This poem by Femmetje de Bruin, who moved in religious circles, is exceptional within the corpus of women's nuptial poetry because of its intensely religious character. ${ }^{57}$ However, like the other female-authored poems I have described thus far, it is also free of any literary ambitions.

There are only a few female poets who seem to have had literary ambitions: Katharina de With (1691-1728) from Utrecht and Anna

\footnotetext{
${ }^{56}$ There is little biographical information on Neeltje Dirksdochter Beths. She was married to Hendrik Lambertsz. ten Cate, a son of the famous Mennonite linguist Lambert ten Cate. She signed one of her nuptial poems as N. Ten Kate.

${ }^{57}$ Schenkeveld-van der Dussen, "Bruiloftsdichten in de tale Kanaäns" reflects on this kind of nuptial poetry.
} 
Maria Paauw (?-1710) from Gouda..$^{58}$ They wrote social poetry within their own elite circles. The nuptial poems they wrote also functioned within the Utrecht and Gouda elite context. Both had their own styles, which differed from the conventional nuptial poetry of the end of the seventeenth century. De With only wrote pastoral nuptial poetry. Her other occasional poetry was also pastoral and we know she had connections in circles of pastoral poets she knew through her father, including Pieter Vlaming and Jan Baptista Wellekens. De With's nuptial poetry should therefore be seen as both a means of networking (within the elite circles of Utrecht) and as part of a literary self-representation. Paauw's poems seemed to have had the same dual function. Paauw wrote evocative, long, epical poems full of classical mythology - just like her other occasional poetry. Her poems share little resemblance to other nuptial poems written at the end of the seventeenth century. Her literary ambitions, however, are obvious - in fact they are often too obvious.

In sum, women wrote different kinds of nuptial poetry. How they used the genre apparently depended on their specific aims. In certain circles it was common enough for women to write nuptial poetry, but publishing it or being commissioned to write it was often impossible or simply unnecessary. Lescailje, however, had these opportunities because she had her own publishing house and literary fame. Furthermore, she needed to do so because she had to make her own living.

\section{Concluding Remarks}

It seems inaccurate to speak of the female transformation of a genre like nuptial poetry. As opposed to some of her female colleagues, most of Lescailje's nuptial poetry conforms to the conventions practised by her contemporaries. Like them, she was able to adapt those conven-

${ }^{58}$ On Katharina de With: Schenkeveld-van der Dussen R., "Katharina Johanna de With (gedoopt Utrecht, 13 februari 1691 - Utrecht, 16 februari 1728). Een pastorale vrouwenkring", in Schenkeveld-van der Dussen R. - Porteman K. (eds.), Met en zonder lawwerkrans 495-498. Henriëtte Elisabeth de With, one of Katharina's sisters, also wrote nuptial poetry. There is little known about her, but her poetry seems comparable to her sister's. I found two nuptial poems by Henriëtte Elisabeth, among them one pastoral poem. The sisters De With also wrote a pastoral dialogue together to commemorate a marriage, but there is no separate publication of this poem. It is printed in De With, Fillis van Scirus 280-285. 
tions to the specific contexts of her poems. This interplay between the social and literary concerns determined the character of the nuptial poems. Still, the appropriation of the genre by individual women can to a large extent be attributed to their womanhood.

An illustration of this can be found in the way Lescailje plays with the conventions regarding the bride's doubts in many of her nuptial poems. Lescailje introduces a theme of freedom within a discourse of negative attitudes towards marriage. The theme is used in many different ways and applies to both literary traditions and social relationships. Traditionally, the bride's doubts are attributed to her shyness and purity - she fears the wedding night. The total absence of these characteristics in the poems of Lescailje can be provisionally interpreted as adhering to a feminist position. Indeed, she instead combines the doubts about marriage with an aversion to marriage that is inspired by the loss of freedom. Moreover, in some cases Lescailje also projects the doubts about marriage onto the groom. These combined factors determine her position in the polemical discourse regarding marriage and womanhood, as described in the introduction. We have seen above how Lescailje's contemporaries also occasionally used this negative discourse about marriage and freedom.

Lescailje thus operates in an existing framework of conventions, but she combines, reverses and exaggerates aspects of it. She does so according to social circumstances. For example, in the poems for her friend Sara de Canjoncle or her patron Willem van Zon, Lescailje uses the negative discourse to emphasise the bond between herself and the bride or groom. The praise for the bridal couple is also increased by it: in emphasising the loss of freedom, Lescailje is able to better express the merits the bride or groom has acquired so far. This function is also present in the poem for Willem van Zon. Another use of the theme is to stress her own openness to becoming a future bride, which only occurs in early poems. Finally, the theme is also used to represent poethood and womanhood.

Although Lescailje does not refer to her own womanhood in most of her nuptial poems and feminist manifestations are not a common feature of her poetry, by emphasising the loss of freedom experienced by some women in getting married, Lescailje implicitly represents herself as an independent woman. She flaunts the fact that she has all the time in the world to write and to run her company and she is happy with this. This particular implication gains strength in poems written for other women writers through the opposition of Lescailje and the 
bride..$^{59}$ The anti-marriage discourse and the focus on the freedom of unmarried women enabled Lescailje to connect herself to other selfemployed and independent women among whom she lived and worked.

In conclusion, the way in which Lescailje deals with the anti-marriage discourse is representative of the way in which she was able to appropriate other conventions of the genre. It can be traced back to literary traditions and connected to social contexts in which her womanhood plays an important role. Lescailje appropriates the genre of nuptial poetry by altering its conventions, while still taking into account the social and literary possibilities and restrictions. She does so in order to consolidate her own social position as a self-employed, writing woman. The poems helped her earn the money she needed to stay autonomous; they helped to secure her position in literary networks and functioned as a defence of her public activities. Lescailje's use of the genre of nuptial poetry is unique in comparison to other women writers. However, the case of Lescailje demonstrates the possibilities of self-representation for women, also within such a conventional genre as nuptial poetry. Conventions could be appropriated.

${ }^{59}$ Grabowsky proposed a similar interpretation in "Katharina Lescailje" 73-76. 


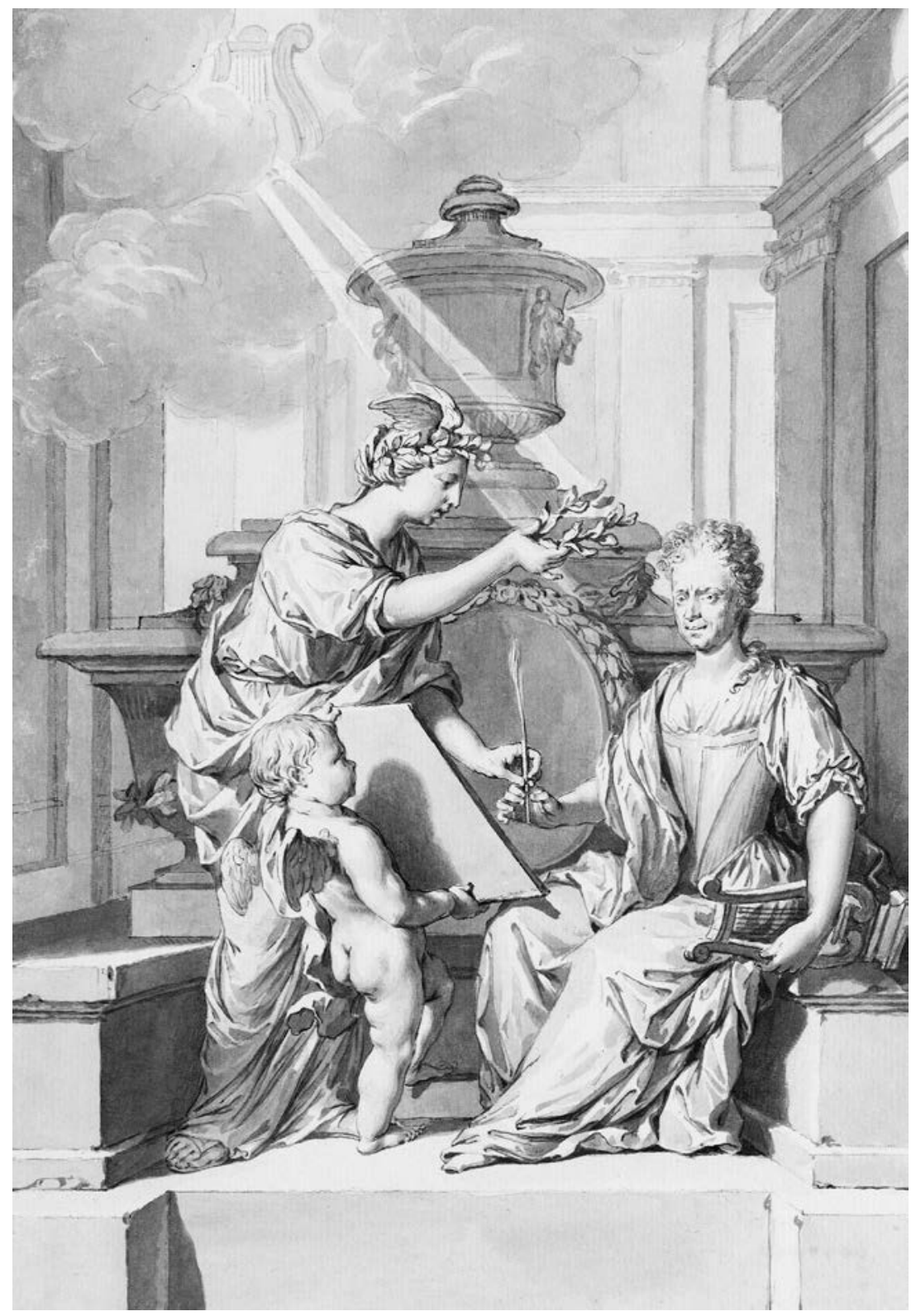

Fig. 1. Nic. Verkolje, Katharina Lescailje (1693). Pencil in grey on black chalk, 23,6 × 16,3 cm. Teylers Museum Haarlem, Inv. nr. PP 780 . 
OP HET

$\begin{array}{llllllll}H & U & U & W & E & L & Y & K\end{array}$

Van de Heer

\section{PIETER KOOLAERT,}

En Mejuffrouw

\section{ELIZABETH HOOFMAN.}

Getround in Haarlem den 23 vari Oegstmaand, 3623 .
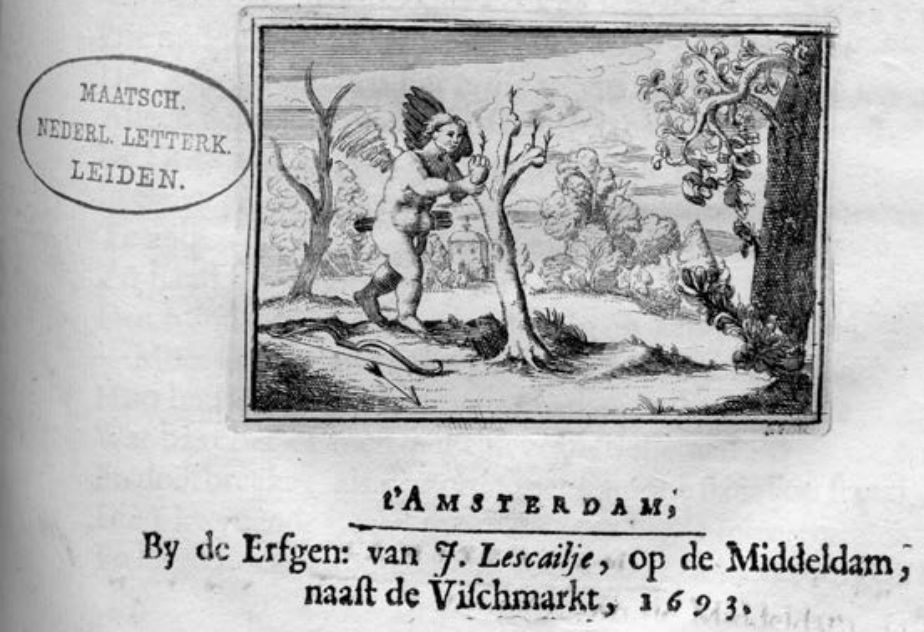

Fig. 2. Title page of Katharina Lescailje et al., Op het huuwelyk van de heer Pieter Koolaert, en mejuffrouw Elizabeth Hoofman. Getrouwd in Haarlem, den 23 van Oegstmaand, 1693. (Amsterdam, heirs of J. Lescailje: 1693). University Library Leiden, UBL 1099 H 18:2. 


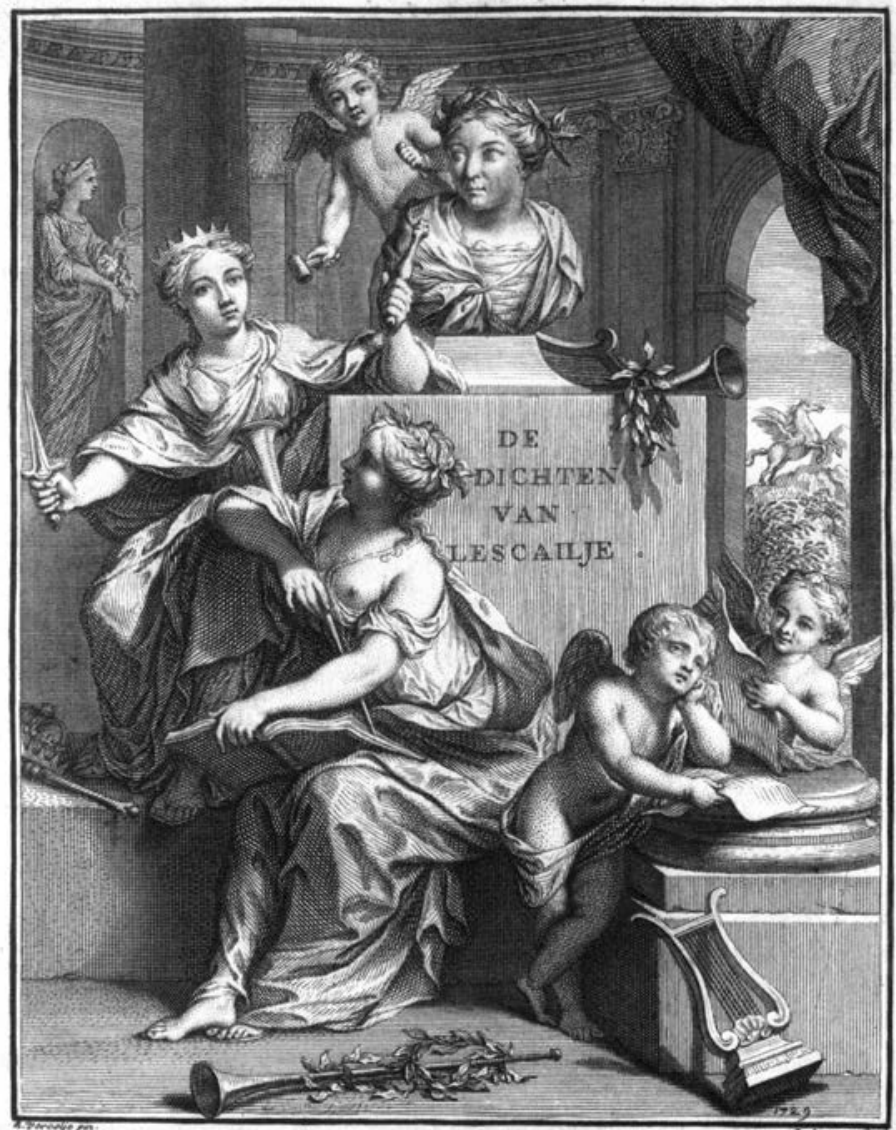

TeAmiteldam, by de Fifgen : van J.Lescan JE en D.RAxk, op deBeursilus.

$$
\begin{aligned}
& \text { BIBLUTHECA } \\
& \text { CONVENTUS } \\
& \text { MEGENSI8. }
\end{aligned}
$$

Fig. 3. Title page of Katharina Lescailje, Tooneel-en mengelpoëzy (Amsterdam, heirs of J. Lescailje en D. Rank: 1731). University Library Utrecht, UBU THO: MEG 10-250/251/252. 


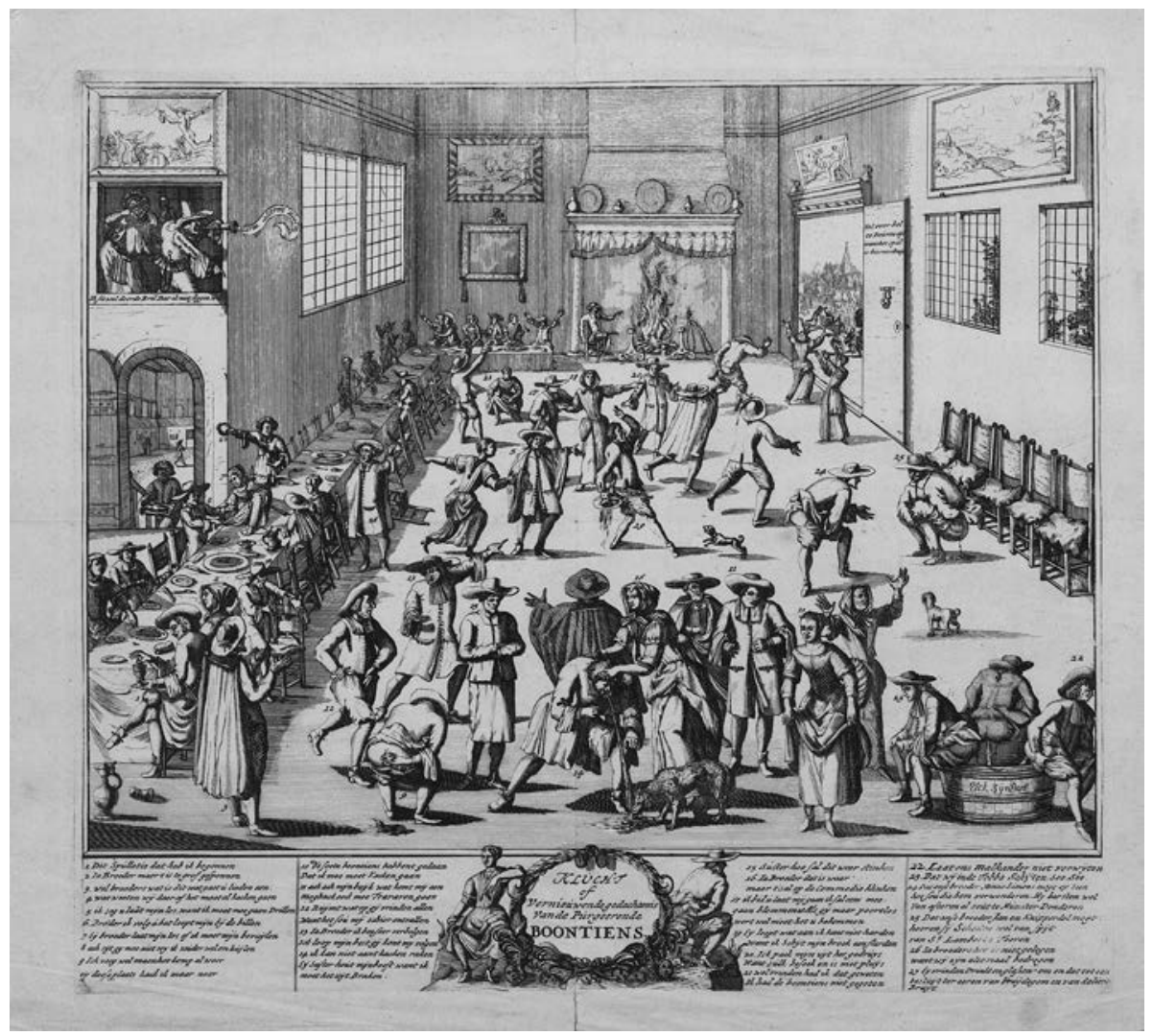

Fig. 4. Klucht of Vernieúwende gedachtenis van de Púrgeerende Boontiens, ca. 1680. Engraving, 35,3 × 39,4 cm. University Library Amsterdam (UvA), Special Collections P00015853. Satirical etching of the extravagant festivities Mennonites organised to celebrate marriages. The wedding guests are all running off to defecate after eating huge amounts of beans during the festivities. 


\section{APPENDICES}

1. Separate publications of nuptial poetry used for this article, in chronological order ${ }^{60}$

Veer C. van der - Bormans S. - Lescailje K. - Pluymer J. - Angelkot H. - Croix P. de la - Lemmers J. - Boschman P. - Soolmans J. - Bogaert A. van den, Huwelykszangen, Ter Bruilofte van de E. Bruidegom Matthias de Wreedt, en de E. Bruidt Barbera Lescailje. In d'Echt verbonden te Amsteldam, den 8/18 van Wintermaand, 1674 (no publisher, no date) [UBL 778 C 57:15].

Lescailje K. - Bafake L. - Pluimer J. - Bidloo G. - Verhoek P. - Croix P. de LA - Hoogstraten D. van, Ter bruilofte van den heere Foannes Antonides van der Goes, der medicijnen doctor, en mejuffrouw Suzanna Bormans (Rotterdam, Abraham van Waesberghe: 1678) [KB 853 A 224].

Lescailje K. - Bidloo G. - Elias M. - Lingelbagh D. - Bosch S. - Ditsom G. van Adriaensz. Gevelman M. - Verhoek P. - Geleyn J. van - Baake L. - Arends T., Op het huuwelyk van den heer Harmannus Amya, en jongkorouw Catharina de Vogelaar. Getrouwd in Amsterdam, den 19 van Wijnmaand 1683 (no publisher, no date) [UBL Portef. 24:5x].

Lescailje K. - Arenius P. - Jansen A. - Rabus P. - Hoogstraten J. van - Bracht K. van - VRIEs A. DE, Parnaskranssen gevlogten op het huwelijk van den heere David van Hoogstraten, der medicinen doctor, en mejuffrou Maria van Nispen. Voltrokken te Dordregt den 28. Van Lentemaend 1685 (Dordrecht, Jan van Hoogstraten: 1685) [UBA OG 01-173].

Lescailje K., Op het Hunwelyk Van de Heer Mr. Simon Muis van Holy, Heeren Arents zoon. En Fongkorouw Anna Elisabeth De Witt, Heeren CornelisDochter. Verëenigd in Dordrecht den 22. van Zoomermaand, 1688 (no publisher, no date) [KB 489 A 9].

Jansen A., Houwlykslof. Ter bruilofte van Theodorus van Born, met Maria vanderSchuuren. [...] (Amsterdam, Dirk Boeteman: 1690) [PBZ Gel. Ged. 133].

Lescailje K. - Hoogstraten D. Van - Pluimer J. - Angelkot H. - Storm J. Bógaert A., Op het huuwelyk van de heer Pieter Koolaert, en mejuffrouw Elizabeth Hoofman. Getrouwd in Haarlem, den 23 van Oegstmaand, 1693 (Amsterdam, Erfgen. J. Lescailje: 1693) [UBL 1099 H 18:2].

Lescailje K., Ter bruilofte van de Heer Antoni Rutgers, en mejuffrouw Maria Rutgers. Getrouwd den darden van Louwmaand, 1694 (Amsterdam, Erfgen. J. Lescailje: 1694) [UBA OG 80 145:40].

Lescailje K., Harderszang ter bruilofte van den heere Facob Alewynz Ghyzen, en jonkurouw Juliana van der Schelling. Getrouwd den 10 van Grasmaand, 1695 (Amsterdam, Erfgen. van J. Lescailje: 1695) [UBA OG 80-245:54].

Bógaert A., Ter bruilofte van den heere Fan Teyler Facobsz. en Maria van Gelyn.Door den echten band verknocht den 12 van Wiedemaand 1695 (Amsterdam, Herman Aaltsz: 1695) [UBA OG 80-245:59].

Jansen, A., Ter bruilofte van Foan Teiler Fakobsz. met Maria van Gelein. Getrouzotden 12 den van Zomermaand, des jaar 1695. Binnen Amsterdam (Amsterdam, Dirk Boeteman: 1695) [UBA OG 80-245:61].

${ }^{60}$ I used all the separate publications with poems by Lescailje, complemented by some publications by other authors on the same occasions. I was not able to consult one publication mentioned in the STCN (Short Title Catalogue of the Netherlands) because it seems to be lost: Op het huuwelyk van [...] Abraham Verhamme en [...] Katharina de Neufville [...] (Amsterdam: Erfgen. J. Lescailje 1700). [UBA OG 65-169:1]. 
N.N. [Lescailje K.], Ter bruilofte van den heere Foan Teyler en jongkurouwe Maria van Geleyn. Getrouwd den 12 van Zoomermaand (Amsterdam, Erfgen. J. Lescailje: 1695) [UBA OG 80-245:60].

Lescailje K. - Arendzs. T. - Bougart A. - 'Alles in 'T welnemen', Op het huuwelyk van den heer David Amoury, en jongkvrouw Maria van Lennep. Getrouwd den xi van Wintermaand, 1695 (Amsterdam, Erfgen. J. Lescailje: 1695) [UBA 80-245:72].

Lescailje K., Ter bruilofte van den heere David Rutgers Isaakz, en Fongkvrouw Debora Bruin. Getrouwd den 3 van Sprokkelmaand, 1697 (Amsterdam, Erfgen. J. Lescailje: 1697) [UBA OG 80-254:95].

Jansen A., Ter bruilofte van den heere David Rutgers Isakszoon, met Debora Bruin. Getrouwt op den 3den van Sprokkelmaand des jaars 1697 in Amsterdam (Amsterdam, Dirk Boeteman: 1697) [UBA OG 80-245:93].

Anonymous, De Bruyloft van monsr. David Rutgers Izaaks, en mejuffr. Dieuwerje Bruyn, gehouden, den 3 February, Binnen Amsteldam (no place, no date) [UBA OG 80-245:94].

Lescailje K. - Fortgens G. - Gysen A. van, Op het huuwelyk van den heer foannes vander Mersch, en jongkvrouw Petronella van Oosterwyk, getrouwd den xxï. van Herfstmaand, 1697 (Amsterdam, Erfgen. J. Lescailje: 1697) [UBL 1118 A 6:159].

Lescailje K., Ter bruilofte van den heere Facob Feitama, en jonkorouw Sara van Lennep. Getrouwd den 5 van Louwmaand, 1698 (Amsterdam, Erfgen. J. Lescailje: 1698) [UBA OG 80-244:1].

Lescailje K. - Arendsz. T. - Bógaert A. - Kaarsgieter F. de, Op het huuwelyk van den heer Gerard Reessen, en jongkvrouw Geertruid van der Keere. Getrouwd den viii. van Zomermaand, 1698 (Amsterdam, Erfgen. J. Lescailje: 1698) [KB Gel.ged. 397].

Lescailje K., Ter bruilofte van den heere Abraham Hoorens, en mejuffrouw Catharina Linnich. Getrouwd den 21 van Zomermaand, 1699 (Amsterdam, Erfgen. Lescailje: 1699) [KB 853 A 250].

Lescailje K. - Regt J. De - G.F. [Gerrit Fortgens] - A.B. - P.S., Ter bruilofte van den heere Daniël Hoorens Cornelisz, en jongkvrouw Margareta Block. Getrouwd den 8sten van Oegstmaand, 1700 (Amsterdam, Erfgen. J. Lescailje: 1700) [KB 853 A 251].

Lescailje K. - Bidloo L., Huuwlykx-wensch aan den E. Dionys Oortman, en jonkorouw Maria Noorddyk. In den egten-staat getreden den 24 van Grasmaand, 1703 (no place, no date) [KB 853 B 2].

Lescailje K., Op het huuwelyk van den heere Abraham Verhamme, de jonge, en jongkvrouw Johanna Maria Slachregen, getrouwd in Haarlem, den 27sten van Herfstmaand, 1705 (Amsterdam, Erfgen. J. Lescailje: 1705) [KB 853 G 169:1].

Anonymous, Bruyds en huuwelijks lof. Op het trouwerbond van den heere Abraham Verhamme, en mejuffrouw Fohanna Maria Slagreegen. In den egt bevestigt den 27 sten van Herfstmaand, in den jaare 1705. Binnen Haerlem (no place, no date) [KB 853 G 169:2].

Lescailje K. - Fortgens G. - Bouman H. - Burg H. van De, Op het huuwelyk van den heere David Leeuw van Lennep, en jongkvrouw Christina Rutgers; getrouwd den 28sten van Sprokkelmaand, 1706 (Amsterdam, Erfgen. J. Lescailje, 1706) [UBA OG 01-300].

Lescailje K. - Storm J. - Boon G. - Hoeven W.V. - Burg H. van den, Ter bruilofte van den heere Isaac Snep den jongen, en mejuffrouw Cornelia Slagregen. Getrouwd den 4den van Grasmaand, 1706 (Amsterdam, Erfgen. J. Lescailje, 1706) [KB Gel. Ged. 400].

G.V.H. - Lescailje K. - Fortgens G. - Burg H. van den - Smids L. - Vingent Y. - J.B.W., Op het huuwelyk van den heere Facob van Lennep, en jongkorouw Susanna Rutgers. Getrouwd den 6den van Bloeimaand, 1706 (Amsterdam, Erfgen. J. Lescailje: 1706) [KB 853 C 141].

Lescailje K. - J.J.O. - L.C. - Burg H. van den, Op het huuwelyk van den heere Fan Hondius, en mejuforouw Elizabeth Visscher, getrouwd den 18den van slachtmaand, 1706 (Amsterdam, Erfgen. J. Lescailje: 1706) [KB Gel. Ged. 189].

Lescailje K. - A.W. - Schermer L. - Anonymous, Op het hunwelyk van den heere Michiel Blok, en jongkurouw Maria van Beeck; getrouwd den 6den van Lentemaand, 1707 (Amsterdam, Erfgen. J. Lescailje: 1707) [KB 853 A 279]. 
G.V.H. - Lescailje K. - Roeters J. - Eeke C. van - Fortgens G. - Bouman H. H.V.B. - W.S. - Hoeven W. van DER, Op het huuwelyk van den heere Joan van Meekeren, en jongkorouw Margaretha Rutgers. Getrouwd den 17 den van Grasmaand, 1707 (Amsterdam, Erfgen. J. Lescailje: 1707) [KB 852 F 410].

Lescailje K. - Rutgers D., Ter bruilofte van den heere David Matheus de Neufville, en jongkurouw Facoba van Gelder, Getrouwd den 18den van Grasmaand, 1708 (Amsterdam, Erfgen. J. Lescailje: 1708) [KB Gel. ged. 295].

Lescailje K. - Voordaagh J. - J.V. - Bruin G. - Houbakker J. - Gaete H. van den, Op het huuwelyk van den heere Jacob Hennebo Adriaansz., en jongkwrouw Magdalena Barnaard; getrouwd, in Haarlem, den 13den van Bloeimaand, 1708 (Amsterdam, Erfgen. J. Lescailje: 1708) [KB 853 A 288].

\section{Nuptial poetry by women (other than Lescailje)}

Beths N.D., in: Huwelyks-wensch, aan den Eerwaarden Jong-man Antonius ten Cate, en de Eerbare Fonge Dogter Margareta Bronkhorst (Amsterdam, Wed. P. Arentsz: 1691) [UBA OG 80-245:14].

Beths N.D., in: Huwlyks wensch an d'eersamen Fongman Herman ten Cate, de Fonge, en d'eerbare Fonge dogter Fozina Bronkhorst (Amsterdam, Dirk Boeteman: 1691) [UBA OG 80-245:17].

Bormans S., in: Huwelykszangen, Ter Bruilofte van de E. Bruidegom Matthias de Wreedt, en de E. Bruidt Barbera Lescailje. In d'Echt verbonden te Amsteldam, Den $8 / 18$ van Wintermaand, 1674 (no place, no date) [UBL 778 C $57: 15]$.

BRUIN F. DE, in: Huwelyks-toorts ontsteken ter bruiloft van [...] Fohannes d'Outrein [...] en [...] Geertruida Sluiter (no place: 1689) [PBZ Gel. ged. 17].

Kate N. Ten, Houwelyxwensch, aan Dirk ten Cate, Dokter der Geneeskunst. Met Foanna Kist (Amsterdam, Dirk Boeteman: 1696) [UBL 1197 B 31:18].

Kopyn S., in: Echtzangen, ter bruiloft van den heere, Willem van Oosterwyk, en jonkurouwe Susanna van Mollem (Amsterdam, Francois Halma: 1706) [UBA OG 80-244:44].

Insma Bruyn A., Wel lievens lof. Ter bruylofte van Siewert Centen, met Fohanna Bruyn (Amsterdam, no publisher: 1695) [UBA OG 80-245:69].

MazeIK P. van, in: Ter bruilofte van Abraham vander Meersch junior, met Katarina Outerloo (Amsterdam, Dirk Boeteman: 1696) [UBL 1197 B 31:19].

MeErsch, K. van, in: Ter bruilofte van Abraham vander Meersch junior, met Katarina Outerloo (Amsterdam, Dirk Boeteman: 1696) [UBL 1197 B31:19].

PaAuw A.M., Zegewens-gezang, op 't vereenen van [...] Nicolâs Mol [...] en [...] Fohanna Alathea de Mey (Gouda, Johannes Endenburg: 1703) [OB Arnhem Kluis 817].

PaAuw A.M., Op het huwelyk van Monsr. Foannes Endenburg [...] en juffr. Alida Ooms (no place: 1701) [UBL Portef 24:42].

PaAuw A.M., Op het trouw-verbond van den heer Daniël Bik [...] en juffrouw Anna Maria Donker van Oukoop (Gouda, Johannes Endenburg: 1701) [UBL Portef 24:14].

PaAuw A.M., Op het egt-verbond van de Hoog-Agtbaaren Heer de Heer en Mr. Gerard van Brandwijk [...] en Mevrouw Agatha vander Burg. (Gouda, Joannes Endenburg: 1700) [UBL Portef 24:23].

PaAuw A.M., in: Heil en Zegen-wens op 't Huwelijk van sr. Foannes Terwe, [...] en [...] Christina Antwerpen (Gouda, Johannes Endenburgh: 1699) [KB 853 A 253:1].

PaAuw A.M., in: Op het huwelijk van den Hoog agtbaaren Heer mijn Heer Frederyk Dumant [...] ende Wel edele Fuffrouw Me Fuffrouw, Maria van Bleiswyk (Schiedam, Laurens van der Wiel: 1699) [UBL Portef 24:39].

PaAuw A.M., in: Op 't Huwelyk van [...] Reyer vander Burch en [...] Agatha vander Burch (Gouda, Wed. Andries Endenburgh: 1694) [KB Gel. ged. 5].

Veer C. van Der, in: Huwelykszangen, Ter Bruilofte van de E. Bruidegom Matthias de Wreedt, en de E. Bruidt Barbera Lescailje. In d'Echt verbonden te Amsteldam, den 8/18 van Wintermaand, 1674 (no place, no date) [UBL 778 C 57:15]. 
Veer C. van Der, in: Houlyx wenschen: Voor de heer Willem Tierens, en de volgeestige juffer Alida Schouten (Amsterdam, Paulus Matthysz.: 1676) [UBL: Portef qu 7: 47].

WITH H.E. DE, in: Bruiloftzangen op het huwelyk van den hoogwelgeboren heer Eger Tamminga [...] en de hoogwelgebore jongkorouwe Izabella Sofia van der Muelen tot Maersbergen, enz. enz. (no place: 1718) [UBL: 186 A 4:36].

Wiтн H.E. DE, in: Huwelykszangen ter bruilofte van de heere Tiberius Beeldsnyder Matroos, der beide Rechten Dokter, en jongvrouwe Alida Margareta Meyn. (Amsterdam, Johannes Oosterwyk: 1718) [UBA: OG: 01-154].

WITH K.J. DE, in: Ter bruiloft van den heere Dirk van Poolsum, en juffrouw Anna Maria van Engelen (Utrecht, Jacob van Poolsum: 1717) [UBL 1197 B 32:16].

With K.J. DE, Herdersgezang ter eeren van [...] Petrus Vuyst [...] ende Barbara Wilhelma Gerlings (Utrecht, Wed. G. Muntendam: 1714) [KB Gel. ged. 732]. 


\section{Selective Bibliography}

Blevins J., Catullan Consciousness and the Early Modern Lyric in England (Burlington: 2004).

Bouman J., Nederlandse gelegenheidsgedichten voor 1700 in de Koninklijke Bibliotheek te 's-Gravenhage: Catalogus van gedrukte gedichten op gedenkwaardige gebeurtenissen in het leven van particuliere personen, Bibliotheca Bibliographica Neerlandica 15 (The Hague: 1982).

Carlin C.L., "Imagining Marriage in the 1690s", Papers on French Seventeenth-Century Literature 28, 54 (2001) 167-176.

DaAmen M. - Meijer A., Catalogus van gedrukte Nederlandse gelegenheidsgedichten uit de zeventiende en achttiende eeuw in de Zeeuwese Bibliotheek te Middelburg (Middelburg: 1990).

Dubrow H., A Happier Eden: The Politics of Marriage in the Stuart Epithalamium (Ithaca: 1990).

Gemert L. van, "Katharina Lescailje (Amsterdam, 26 september 1649-Amsterdam, 8 juni 1711). Schrijfster annex uitgeefster", in Schenkeveld-van der Dussen R. Porteman K. (eds.), Met en zonder lauwerkrans: Schrijuende vrouwen uit de vroegmoderne tijd 1550-1850. Van Anna Bïns tot Elise van Calcar (Amsterdam: 1997) 396-402.

— , "Hiding Behind Words? Lesbianism in 17th-Century Dutch Poetry", Thamyris: Mythmaking from Past to Present 2, 1 (1995) 11-44.

— , "De vrouwenzucht van Katharina Lescailje", in Gelderblom A.J. - Duits H. Smits-Veldt M.B. (eds.), Klinkend boeket: studies over renaissancesonnetten voor Marijke Spies (Hilversum: 1994) 143-149.

Grabowsky E., "Katharina Lescailje (1649-1711) en de 'vrouwenzucht': schijn of werkelijkheid?", Mededelingen van de Stichting Jacob Campo Weyerman 23, 2 (2000) 65-79.

JEu A. DE, 't Spoor der dichteressen'. Netwerken en publicatiemogelijkheden van schrijvende vrouwen in de Republiek (1600-1750) (Hilversum: 2000).

Lescailje Katharina., Tooneel- en mengelpoëzy, 3 vols. (Amsterdam, Erfgen. Lescailje en Dirk Rank: 1731).

—_, "Huwelijkszangen", in: Lescailje, Tooneel- en mengelpoëzy II, 3-314.

Miller N.K., "Changing the Subject: Authorship, Writing and the Reader", in Burke S. (ed.), Authorship: From Plato to the Postmodern: A Reader (Edinburgh: 2000) 193-211.

Nieuweboer A., "Haarlems literair leven in gelegenheidsgedichten (1680-1770)", in Grootes E.K. (ed.), Haarlems helicon. Literatuur en toneel te Haarlem vóór 1800, (Hilversum: 1993) 187-201.

Schenkeveld-van der Dussen M.A., "Poëzie als gebruiksartikel: gelegenheidsgedichten in de zeventiende eeuw", in Spies M. (ed.), Historische letterkunde: facetten van vakbeoefening (Groningen: 1984) 75-92.

—_, "Hochzeitsdichtung und christlicher Glaube. Einige Epithalamien Niederländischer Dichter", Jahrbuch fir Internationale Germanistik A, 8 (1980) 31-37.

_ , "Christus, Hymenaeus of de 'Teelzucht"', in Witstein S.F. - Grootes E.K. (eds.), Visies op Vondel na honder jaar. Een bundel artikelen ter gelegenheid van de driehonderdste sterfdag van Foost van den Vondel (The Hague: 1979) 11-25.

_- "Theorie en poëzie: een epithalamium van Six van Chandelier", De nieuwe taalgids 72 (1979) 391-398.

- "Bruilofts- en liefdeslyriek in de 18e eeuw: de rol van de literaire conventies", De nieuwe taalgids 67 (1974) 449-461.

Sahenkeveld-van der Dussen R. - Porteman K. (eds.), Met en zonder lauwerkrans: Schrijvende vrouwen uit de vroegmoderne tijd 1550-1850. Van Anna Bijns tot Elise van Calcar (Amsterdam: 1997).

SpIes M., "Betaald werk? Poëzie als ambacht in de 17e eeuw", Holland. Themanummer Kunst in opdracht in de Gouden Eeuw 23 (1991) 210-224. 
Tufte V., The Poetry of Marriage. The Epithalamium in Europe and Its Development in England (Los Angeles: 1970).

VIsser P., "Aspects of Social Criticism and Cultural Assimilation: The Mennonite Image in Literature and Self-Criticism of Literary Mennonites", in Hamilton A. Voolstra S. - Visser P. (eds.), From Martyr to Muppy. A Historical Introduction to Cultural Assimilation Processes of a Religious Minority in the Netherlands: the Mennonites (Amsterdam: 1994) 67-82. 